\title{
Wittgenstein og den pragmatiske vending
}

Möge Gott dem Philosophen Einsicht geben in das, was vor allen Augen liegt.

Wittgenstein

Udtrykket "pragmatisk vending" anvendes her som etikette for et skift, der finder sted over en bred front $i$ store dele af filosofien i sidste halvdel af det 20 . århundrede. Så forskellige tænkere som f.eks. Habermas, Cavell, Taylor, Rorty, Lyotard, Wellmer og Apel tager del i det.

Udtrykket bruges her i forlængelse af og under inspiration fra, hvad der kaldes den "lingvistiske vending" i filosofien i vores århundrede. Det skal markere, at ganske vist overses de sprogfilosofiske landvindinger ikke, som er gjort i dette århundrede. Alligevel er der fremkommet en iøjnefaldende affetichering, kunne man måske kalde det, af tilliden til, at sproget som sådant og isoleret betragtet skulle rumme nøglen til altets gåde.

Ordet pragmatisk skal derfor ikke ses i forlængelse af den klassiske pragmatisme, der allerede i 1908 af Lovejoy blev hævdet at have mindst tretten grundforskellige udgaver. Hen igennem de tretten samt senere tilkomne pragmatismer foreligger der to fællestræk - nemlig et epistemologisk og et ontologisk - som hver især markant adskiller sig fra, hvad der gør sig gældende i det, der her kaldes en "pragmatisk vending":

A) Således gælder efficiens som central: at noget er, og hvad det er - dette har sin bestemmelsesgrund $i$, at det er effekt, og at det selv frembringer effekter. Som konsekvens af denne effekt-kæde-struktur gælder, at intet grundbegreb kan forekomme i singularis. Det giver kun mening at tale om meninger, sandheder, betydninger, nyttigheder etc.

B) Og således gælder endvidere at de klassiske pragmatismer har søgt at være i overensstemmelse med et naturvidenskabeligt ideal, såvel hvad angår proceduralitet, som hvad angår sandhedskriterier og sandhedsformer.

F.eks. gælder, at sandhed er noget, som viser sig i form af efficiens samtidig 
med, at den kun forekommer, for så vidt som den optræder i analogi med, hvad der tæller som sandhed i naturvidenskaberne. Fra disse arves ud over efficiens evidens: sandhedens indhold (dens væsen) er efficiens, og dens måde at være til på (dens væren) er i form af evidens.

Måske er det nødvendigt at bemærke, at det nye (her kaldet pragmatisk vending) ikke består i en negation af de to momenter (efficiens og evidens): ingen tænkning vil kunne ophøje fravær af efficiens og evidens som mål i sig selv uden at opgive sig selv og fremme notorisk tågesnak som ideal. Det drejer sig derfor ikke om negation, men om en sprængning, der indtræder formidlet over en forståelse af, at såvel efficiens som evidens er situeret og forekommer i mange måske beslægtede, men ikke til enhed reducerbare former. Et eksempel på sprængningen gav Wittgenstein i følgende passus: " "Ueksakt" er egentlig en fejl og "eksakt" en ros. Og det vil vel sige: det ueksakte når ikke sit mål så fuldkomment som det mere eksakte. Dog - da drejer det sig om, hvad vi kalder "målet". Er det f.eks. ueksakt, når jeg ikke angiver afstanden fra os til Solen med en meters nøjagtighed; eller ikke til snedkeren angiver bordets bredde med 0,001 millimeters nøjagtighed?" (Philosophische Untersuchungen, § 88).

Men, hvad er da det karakteristiske for den påståede "pragmatiske vending"? En sådan karakteriserende etikette lever af, hvad den polemisk distancerer sig fra, nemlig den (forudgående) "lingvistiske vending". Det er denne vending, der nu vendes pragmatisk. Den ophøjede status, som sproget i og for sig selv blev forlenet med i megen lingvistisk filosofi, der kom til at forveksle sig med lingvistik som videnskab, opgives i den pragmatiske vending som ugyldig. Sproget har ikke denne alt andet bestemmende og autarkiske rolle, som det er blevet tilskrevet.

Ikke lemfældigt, men vagt og alligevel overordnet, kan den pragmatiske vending stikordsagtigt karakteriseres ved: defundamentalisering, indstilling på provisoriskhed, sans for pluralitet, mistillid til enhver eneretshævdende virkelighedsbeskrivende og -ordnende kode.

De faktiske enheder af $\mathrm{i}$ hinanden indlejrede sprogspil og livsverdener, kan der ikke gås bag om. Nok er de til stede - man kan jo bl.a. referere til dem. Men de er ikke suverænt til rådighed - bl.a. derfor kan man ikke omgås dem, som lod de sig ordne og håndtere ud fra et privilegeret ståsted, der selv skulle ligge uden for alle andre livsverden-sprogspilskonstellationer. Troen på at filosofi eller for den sags skyld videnskab eller kunst skulle udgøre sådanne privilegerede bastioner er netop en naivitet $\mathrm{og}$ en hovmodighed, der forlades i den pragmatiske vending.

Måske er det første gang i den occidentale tænknings historie, at tanken kan besinde sig på sin egen fundamentale vilkårlighed - uden at det sker under dramatiseret nihilisme. En sådan er i dag rent ud teatralsk - og nix weiter.

De følgende overvejelser har Wittgenstein som centralfigur. Jeg har dog i 
væsentligt omfang inddraget Heidegger. Jeg har vanskeligt ved at holde dem adskilt. Omend de er markant forskellige i stil, facon, ordvalg, skrivemåde, selvhøjtidelighed etc. - og endskønt de optrådte så udpræget forskelligt på deres institutioner og i deres miljøer, er der noget ved dem, der bevirker, at jeg har svart ved at holde dem adskilt. Der er ingen fare for at forveksle dem, eller for ikke at kunne skelne dem fra hinanden. De glider ikke diffust over i hinanden. Derimod klæder deres tanker hinanden så godt, at de - for mig - hører sammen. Derfor er det vanskeligt at skille dem ad, men let at undgå at sammenblande dem.

Det er min opfattelse, at Heidegger og Wittgenstein i en række grundspørgsmål konvergerer. Men ikke nok med det. De supplerer også hinanden i perspektivet af en nutidig refleksion. At der så også notorisk foreligger divergens henigennem konvergenserne - dét behøver man næppe at understrege, efter at et par generationer ikke har kunnet se eller sige andet.

Wittgenstein, hvis hundredeårs fødselsdag man fejrer i tohundredeårs jubilæet for Den Franske Revolution, spillede en rolle i den lingvistiske vending. Faktisk kom han forud for dennee til to gange at figurere som initiator eller fortæenker for retninger i sprogfilosofien. Hans Tractatus (1921) blev i den logiske positivisme opfattet som det vigtigste grundlagsskrift. En generation senere var hans Philosophische Untersuchungen (1952) uomgængelig for den analytiske sprogfilosofi.

I dag konturerer en tredie impuls sig tydeligere og tydeligere: Wittgensteins filosofi har haft overordentlig stor betydning for det fænomen, som ovenfor blev kaldt en pragmatisk vending.

En række formelle og indholdsmæssige træk deler Wittgenstein på disse punkter med Heidegger (også født 1889), som han i samtiden aldrig kunne tænkes sammen med. Var Wittgenstein både den logiske positivismes og den analytiske filosofis grundlægger, så figurerede Heidegger ikke mindre prominent, hvad angår eksistentialismen (Sartre) og hermeneutikken (Gadamer). Og hvad der hævdes om Wittgensteins rolle for en drejning af filosofien bort fra det lingvistiske i retning af det pragmatiske - det samme kan hævdes om Heidegger.

$\mathrm{Ja}$, måske forholder det sig endog således, at det er de to tænketraditioners (Wittgensteins og Heideggers) nutidige samspil og tagen notits af hinanden, som udvirker en pragmatisk vending.

\section{III}

"Filosoffen er ikke borger i et tænkefællesskab. Det er det, der gør ham til filosof" (Zettel, 455) - således skrev outsideren Wittgenstein, i et føleligt ubehag ved 
filosofisk skoledannelse. Nærliggende er det at antage, at han på daværende tidspunkt har haft den logiske positivisme i tankerne, endsk ønt udtalelsen også for ham har haft gyldighed i al almindelighed.

En af de ledende logiske positivister gav følgende signalement af den nye måde at filosofere på - en filosoferen, der jo påberåbte sig Wittgensteins Tractatus: "Den nye måde at filosofere på er opstået i snæver kontakt med arbejdet i fagvidenskaben, især matematik og fysik. Det har til følge, at den strenge og ansvarsbevidste grundholdning, som præger den forskende videnskabsmand også må tilstræbes som grundholdning hos den filosofisk arbejdende, medens den hidtidige holdning blandt mere gammeldags filosoffer snarere ligner digterens holdning. Denne nye holdning ændrer ikke alene tænkestilen, men også opgaverne, ja, problembearbejdningen. Salledes er det ikke længere den enkelte filosofs opgave i en enkelt koldblodig handling at oprette en fuldstandig og afsluttet filosofisk bygning. Hver enkelt filosof arbejder derimod på sin bestemte plads inden for den ene og eneste ene enhedsvidenskab". Forfatteren hed Rudolf Carnap. (Der citeres fra hans Der logische Aufbau der Welt, opr. Wien 1928; Hamburg 1961, pg. XIX).

Teamworkfilosofi var for Wittgenstein hele forfatterskabet igennem en vederstyggelighed, ja nærmest en contradictio in subiecto. Heri mindede han også om Heidegger. Til grund for begges tilsyneladende arrogance i forhold til kollektivitet i det filosofiske projekt lå en opfattelse af, at det kun var muligt at være filosof, hvis og når man tænkte op imod filosofien. Ensomheden i tænkningen var ikke en romantisk grille, men en konsekvens af kulturel tabserfaring. En erfaring, der var Wittgensteins såvel som Heideggers, og som de delte med størsteparten af deres mellemeuropæiske generation af intellektuelle.

Den amerikanske filosof Stanley Cavell siger i bogen Pursuits of Happiness om Wittgenstein og Heidegger: "De har, tror jeg, en række vigtige træk til fælles. Et af disse træk viser dem som efterkommere af Kant, nemlig deres fortsatte respekt for og interpretation af skepticismens trussel - muligheden for, at den verden, vi ser, ikke er verden, som den er, at verden ikke er tilgængelig for menneskelig viden eller kontakt. Et andet fællestræk fremkommer af det første, nemlig deres fundamentale optagethed af hverdagslivets kendsgerning og begreb samt deres krav om den menneskelige tænknings VENDEN OM - i Wittgensteins tilfælde TILBAGE TIL det hverdagsagtige (ordinary), til det liv, ens sprog skal dele med andre; i Heideggers tilfælde BORT FRA, hvad der er blevet af dette liv og således af sproget" (op.cit., pg. 271, fremhævelse af S.C.; Harvard 1981).

Hos Heidegger var en udløber heraf insisteringen på at lytte. Hos Wittgenstein blev tavsheden signum på et træk i menings- og betydningsrefleksionen, nemlig grænsen.

Wittgensteins kritik af den logiske positivisme kan kort sammenfattes i 
følgende tre punkter, der til dels rammer hans egen Tractatus, men kun til dels. A) Et ords betydning er ikke dets verifikative omstændigheder. Og mening er ikke opløselig i betydning. B) Naturvidenskaben eller logikken skal ikke foreskrive den filosofiske tænkning et ideal. Bortset fra den restringerede eksakthedsnorm, overser naturvidenskab og logik endeligheden, også den endelighed, som den filosofiske tænkning må besinde sig på som det, den er indfældet i. C) En-hver (filosofisk) enhedsvidenskabelig bestræbelse må afvises som megalomant selvbedrag, da alle (sofistikerede) sprog er henvist til naturlige sprog (modersmål), som man ikke kan komme bag om; et sprog, der fundamentalt set er ubegrundeligt, og som ikke bør hypostaseres. Ideen om et enhedsprog, en enhedstale og en enhedsskrift er i bedste fald naiv, i værste fald diktatorisk.

I tilknytning til - og vel som baggrund for - kritikken af den logiske positivisme er der nogle træk, som helt overordnet karakteriserer Wittgensteins tænkning, ja, som fuldbyrdes i den.

Således demonstrerer filosoffen i sin filosoferen, at der er indtruffet et skisma mellem filosof og filosofi. Når det, som før sagt, gælder, at man kun kan være filosof, hvis man går imod filosofien, så har det forudsætninger, og så må det vise sig. Hvad angår det sidste, så har det et tydeligt nedslag i Wittgensteins stil eller måske rettere facon. Hvad der kan tage sig ud som mærkværdig uformåen og besynderlig kejtethed, er langt snarere end en styret fremstillingsmodus et vidnesbyrd om Wittgensteins store tvivl over for syntese og ligefrem diskursiv orden. Den vildrede, der i så høj grad gør sig gældende i hans facon, er ægte. Deraf kommer et par markante træk. Således lapidaritetens patos, der er så karakteristisk for hans skrivestil. Henføres til samme kilde må vel også det fragmentariske. Det fragmentariske og ikke aforistiske, for Wittgensteins bemærkninger er ikke afsluttede, afsluttelige eller hvilende i sig selv. De er just fragmenter af og til en sammenhæng, som ikke er, og som måske aldrig kan være. På dette punkt, som i øvrigt på en række andre, er der en slående parallel mellem Wittgenstein og hans samtidige Walter Benjamins kredsen om det allegoriske i kontrast til det symbolske.

Hvad angår grundlaget for skismaet mellem filosof og filosofi, så har det rødder i et treleddet tabskompleks, som få vel har følt så påtrængende og ingen anden fillosof $\mathrm{i}$ det tyvende århundrede forholdt sig så konsekvent til som Wittgenstein. Naivitetstab i forhold til verden, selvfølgelighedstab i forhold til den filosofiske tradition og fortrolighedstab i forhold til sproget - dette er det treleddede kulturelle tabskompleks, som Wittgensteins filosofi indoptagende reagerer på. Hans stil er det konsekvente mimetiske udtryk for fænomenet.

Aldrig før har filosofi og filosoferen så intensivt været præget af tilbagekaldelsen. Skepticisme, solipsisme, agnosticisme osv. - det er positioner, der nok markerer tvivl og forbehold, ingen af dem rummer dog nogen egentlig revoka- 
tion, forstået som et vedvarende dementi af alt, som siges. Endog af dementiet selv. Den sidste paragraf i Tractatus - hvor der tales om det, der ikke kan tales om - udtrykte et generationstypisk træk ved den bedste europæiske filosofi i dette århundredes første halvdel. Revokation er da også et centralmoment ved Heideggers tænkning og ved Adornos filosofi. Sammen med Wittgenstein sagde de, når de filosoferede, noget, som deres egen filosofi dementerede i det sagte. Adornos indledende kommentar angående kunsten i hans posthumt udgivne hovedværk Ästhetische Theorie kan udstrækkes til også at gælde filosofien. Han sagde: "Det er blevet selvfølgeligt, at intet af det, som angår kunsten, er selvfølgeligt, hverken i kunsten selv eller i dens forhold til helheden, ikke engang dens eksistensberettigelse er længere selvfølgelig "(Gesammelte Schriften, Ffm, 1972, pg. 9).

\section{IV}

Men det var ikke bare den logiske positivisme, som Wittgenstein både kom til at figurere som grundlægger og kritikker af. Noget lignende gør sig gældende for den analytiske filosofi. Den sene Wittgensteins tænkning blev - og bliver især i det angelsaksiske - taget til indtægt af en række fagfilosofiske skoledannelser, der som regel ikke har noget imod at blive kaldt analytisk filosofi. I modsætning til kritikken af den logiske positivisme er der - velsagtens af historiske grunde ikke overraskende - få direkte afvisninger af dette fænomen hos Wittgenstein.

Der er dog karakteristika ved analytisk filosofi, som enhver uhildet læser kan se, må have budt Wittgenstein imod. Således dens selvhøjtidelighed, således dens menighedslignende kollektivitet, dens mangel på "ensomhed", således dens notoriske fravær af "dybde", og således dens finden sig til rette i og med en verden, der ikke længere undrer. Kort sagt dens plathed og mangel på forrykthed - midt i al begrebssofistikering. Plathed i den betydning, som Wittgenstein angav som forårsaget af "Loss of Problems": "Mange filosoffer (eller hvad man skal kalde dem) lider af det, man kan kalde "Loss of problems", "problemtab". Alt forekommer dem da ganske simpelt, og der synes ikke længere at eksistere dybe problemer. Verden bliver plat og mister enhver dybde; og hvad de skriver, bliver uendelig overfladisk og trivielt" (Zettel, 456).

Få er de steder, hvor Wittgenstein direkte kommenterer pragmatismen. Ifølge Wittgensteineleven Malcolm skal Wittgenstein, der var storkonsument af amerikanske knaldromaner, engang have sagt, at amerikanerne skulle holde sig fra filosofien og i stedet beskæftige sig med, hvad de kunne, nemlig skrive knaldromaner. Dette kunne englænderne til gengæld ikke. Så løsningen var denne: englænderne skulle sende filosofi til USA, og amerikanerne betale med knaldromaner. Amerikansk filosofi var på dette tidspunkt i høj grad præget af Deweys pragmatisme. 
Et af de få steder, hvor Wittgenstein kommenterer pragmatismen lyder: "Hvis jeg vil give træblokken en bestemt form, så er dét slag rigtigt, som frembringer denne form. Derimod kalder jeg ikke argumentet for rigtigt, fordi det har den $\emptyset$ nskede effekt (pragmatisme). Snarere kalder jeg udregningen forkert, endskønt de handlinger, som er frembragt af resultatet, har ført til det ønskede mål. Sammenlign med vitsen: A fortaller B, at han har scoret hovedgevinsten i lotteriet. Han havde på gaden set en æske, hvorpå tallene 5 og 7 stod. Nu havde han regnet: 5 gange $7=64,0 g$ han havde satset på tallet 64 . B: Ja, men 5 gange 7 er dog ikke 64! A: Her scorer jeg hovedgevinsten, og så vil han alligevel belære mig!" (Philosophische Grammatik, 133).

Vi kan per konsekvens sammenfatte Wittgensteins kritik af, hvad han forstod ved pragmatisme, i følgende punkter: 1) I modsætning til, hvad pragmatismen direkte eller indirekte antager, så er videnskab/naturvidenskab ikke model for viden overhovedet. Den er en vidensform blandt andre, og den er ikke mere fundamental, rigtigere eller vigtigere end andre vidensformer. Den videnskabelige sandhedsnorm - eksaktheden - er selv situeret, og ikke idealiserbar. 2) Verden er ikke indbegrebet af, hvad der naturvidenskabeligt lader sig udsige om den, og hvad der lader sig manipulere i forlængelse af en naturvidenskabelig optiks interesse for implementering. Sagt med Heideggers termer: verden er ikke indbegrebet af til- og forhåndenheder ( $\mathrm{Zu}$ - und Vorhandenheiten). Verden er heller ikke indbegrebet af det værende. Afgørende er, som Heidegger sagde det: "at "verden" netop betyder menneskets eksistens i historisk samh ørighed (geschichtlichen Miteinander) og ikke dets kosmiske forekomst som art blandt de levende væsener" (Vom Wesen des Grundes, Ffm, 1965, pg. 35). 3) Nytte er ikke en alt andet overordnet størrelse, og den kan i sig selv ikke karakterisere det menneskelige som sådant.

De tre momenter er konsekvenser af Wittgensteins sprogrefleksion, som lapidarisk kommer til orde i følgende: "Sproget er for os ikke defineret som en indretning, der tjener bestemte formål" (Zettel, 322). Og "Du må betænke, at sprogspillet så at sige er noget uforudsigeligt (Unvorhersehbares). Jeg mener: det er ikke begrundet. Ikke fornuftigt (eller ufornuftigt). Det står der - lige som vort liv" (Über Gewissheit, 559).

\section{V}

Der er gjort opmærksom på konvergens mellem Wittgenstein og Heidegger. Den findes også ex negativo i relationen til klassisk filosofisk pragmatisme. Hele Heideggers filosofi - altså før som efter die Kehre - er jo en anfægtelse af opfattelsen af verden som indbegrebet af et sammensurium af for- og tilhåndenheder. Sådan er verden ikke, men den kan se ud til at være det, fordi den næsten restløst 
bliver gjort til det i konsekvens af den metafysik, som Heidegger, hen igennem forfatterskabet, daterer længere og længere bagud i tid. Stationer for den stedse mere tilbagedaterede metafysik er Kant, Descartes og Platon. Nogle konsekvenser af denne spekulative OG anonymt virkende metafysik var: den ophøjede det almene frem for det særegne; den så bort fra, hvad der ikke gik op i begrebet, ja, begrebet blev så at sige det onto- såvel som det epistemologisk konstitutive; den så flot hen over tiden, som var den kun en ydre og egentlig ret så ligegyldig omstændighed; ligeledes var endeligheden fraværende som andet end privatio, og det hvad enten der var tale om mennesket, tanken eller virkeligheden; og sluttelig sondres der ikke i denne metafysik mellem, hvad mennesket er herre over, og hvad det aldrig kan blive herre over, også selv om det måtte være historisk.

Hvad der i Heideggers forfatterskab blotlægges vedrørende den spekulative metafysik, rummer kritikpunkter, som også var Wittgensteins. Heidegger ville erstatte filosofi med tænkning, fordi enhver filosofi - ifølge Heidegger - som selvstændig og positiverbar aktivitet nødvendigvis må forskrive sig til praktisering af metafysik. Filosofi er metafysisk religion, og filosofferne dens prasteskab. Til dette er der en mere end vag parallel hos Wittgenstein, for hvem det gjaldt, at egentlig findes der ingen filosofiske problemer - men det er betænkeligt, at filosofiske problemstillinger stiller sig i vejen for forholdet til verden. Filosofiens opgave er at høre op!

Et sted siges (citeret hos A. Kenny fra et af de efterladte notater fra Wittgensteins hånd): "Når et menneske med "sund fornuft" læser en tidligere filosof, tænker han (og ikke uden ret): "lutter meningsløshed". Når han hører mig, tænker han : "lutter kedelige selvfølgeligheder!". Atter med rette. Og således har filosofiens synsvinkel ændret sig" (Schriften, Beiheft 3,30).

Heidegger ville historisk og fylogenetisk tilbage (forstået som dette at gøre opmærksom på) til en tilstand før filosofien, for at komme fri af den nu næsten absolutte værensglemsel, som filosofien har affødt og medført. Wittgenstein ville (ontogenetisk og socialisationsmæssigt) tilbage til en tilstand, som ganske vist ikke kan bestemmes som førkulturel, derimod som førteoretisk og førfilosofisk. Det er denne tilstand, som skaber det, der tager sig ud som genuine filosofiske problemer. Men endnu vigtigere er det, at det er den samme baggrund, ud fra hvilken de filosofiske problemer eventuelt kan opløses.

I begge tilfælde kan den formidable indsats og den intensive given sig i kast med filosofien som problem stå i relation til en erfaring af, at den filosofiske finden sig til rette i og med verden (som praktiseret og udtalt i positivismen) manglede overbevisende styrke og - i bogstaveligste forstand - troværdighed. Samtidig hermed var klassisk skepticisme og solipsisme indset som i bund og grund illusorisk og selvdementerende. "Skepticismen er IKKE umulig at modsige, men 
åbenlys meningsløs, når den vil betvivle, hvor der ikke kan spørges. Thi tvivl kan kun forekomme, hvor der er et spørgsmål: et spørgsmål kun, hvor der findes et svar, og dette kun, hvor noget kan siges" (Tractatus, 6.51, fremh. af W.). Skepsis kunne hermed ikke udsiges. Den var alene mulig - og for Wittgenstein utvivlsomt påtrængende virkelig - i form af foruroligende uudsigelighed.

Fælles for Wittgenstein og Heidegger var en erfaring af, at vores relation til verden før alt andet er en relation i verden. Derfor er mit forhold til verden mere intimt, mere nært og mere tæt, men også mere uoverskueligt, mindre gennemskueligt og udtaleligt end det suggereres i form af filosofiens (og især, men ikke kun bevidsthedsfilosofiens) spørgsmål om tro og viden. F.eks. som disse spørgsmål lyder, når der spørges i stil med: Hvordan kan jeg vide, at verden eksisterer? Hvorfor tror jeg, at den eksisterer?

\section{VI}

Der er grund til at antage, at Wittgenstein og for den sags skyld også Heidegger ville have sig frabedt at blive tillagt intention om at bidrage til en pragmatisk vending i filosofien. Der var utvivlsomt for meget i den pragmatisme, de kendte, som bød dem imod. Til trods herfor kan udtrykket "pragmatisk vending" have en berettigelse, ja, siges at ramme sagen. Nemlig den, som Wittgensteins filosofi har været med til at præge. Det er nævnt, at betegnelsen ikke skal lede tanken hen på noget i stil med en renaissance for klassisk filosofisk pragmatisme. Det er også nævnt, at betegnelsen på en gang ønsker at holde erindringen om den lingvistiske vending intakt, samtidig med at dennes hypostase af sproget sprænges.

Lidt i stil med hvad Hegel i Encyklopædien kalder "Stellungen des Gedankens zur Realität" må den "pragmatiske vending" siges ikke at være reducerbar til en art filosofisk mening eller i det hele taget at være forbeholdt filosofien. Det er snarere udtrykket for en indstilling til - en stilling i - verden. En indstilling, der er så civilisatorisk og kulturelt bred, at den ikke lader sig identificere alene via dens filosofiske udtryk og destillater. Hvori består den?

Den "pragmatiske vending" er benævnelsen for en indstilling i og til verden, hvor det karakteristiske er, at virkeligheden erfares og omgås som hverdagsagtiggjort: ikke som trivialitet, banalitet, vulgaritet eller som gennemtrængt massificeret (som Baudrillard vedvarende hævder det), men som hverdagsagtig uden at denne hverdagsagtighed længere bærer præg af at stå i modsætning til en zone (en tid, et rum), der adskiller sig fra den. Ej heller er hverdagsagtigheden af en sådan art, at den fremstår som resultatet af en proces. Der er - om man vil - tale om en Entzauberung, der er så gennemgående og gennemf $\varnothing \mathrm{rt}$, at selve processen, der har ledt frem til den, er ladt bag den. Og således skulle fænomenet med et i forvejen uoversætteligt ord egentlig ikke hedde Entzauberung, men Entzau- 
berheit. Her er metafysik ophørt med at kunne være et spekulativt system, hvilket ikke er det samme som, at enhver metafysik er ophørt. I modsætning til et klassisk dogme i og fra oplysningstiden gælder, at der ikke nødvendigvis er en kontradiktion mellem modernitet og metafysik. Uspekulativ metafysik (som altså ej heller er notorisk tågesnak) er et nok så moderne fænomen. Herom vidner meget store dele af f.eks. Løgstrups Metafysik. Det hverdagsagtige er selv hele gåden - det sublime. Med en betegnelse inspireret af Walter Benjamin kan man tale om det profanes aura - eller det immanent ophøjede.

Man kan hen over dette fænomenkompleks sætte betegnelsen: endelighedserfaring. I og for filosofiens vedkommende anvender jeg betegnelsen "pragmatisk vending" for denne erfaring. Filosofien indoptager og udtrykker endelighedserfaringen $\mathrm{i}$ form af en pragmatisk vending. Men fænomenet er som sagt langt bredere end, at det lader sig indkredse eksklusivt i filosofien. Det lader sig opspore i alle traditionelle kunstarter, i film, i etiske normændringer osv. (Det har jeg søgt at vise i bogen Tendenser - omkring pragmatik, kunst og modernitet, 1988).

For første gang er det moderne ikke længere et projekt, men et vilkår, hvor den moderne verden faktisk beboes i al sin modernitet. Hverdagen tilegnes som noget, man kan være hjemme i, ikke på trods af det moderne, ej heller på grund af det, men sammen med det. En række fænomener i kunsten, arkitekturen og i hverdagslivet bevidner forholdet. Jeg anfører to eksempler.

Marshal Bermanns bog All that is solid melts into air er en lang kærlighedserklæring til fænomenet. Et sted skriver han om den amerikanske byarkitektur-teoretiker Jane Jacobs bog The Death and Life of Great American Cities: "Jeg tror, at hendes bog spillede en afgørende rolle i modernismens udvikling. Dens budskab var, at meget af den mening, som moderne kvinder og mænd så desperat ledte efter, $\mathrm{i}$ virkeligheden lå overraskende i nærheden (close to home), tæt på deres livs overflade og umiddelbarhed. Det var helt i orden dér, hvis vi blot kunne lære at grave". Et andet sted udtaler han bogens credo: "Selv om moderniseringsprocessen udbytter og truer os, bringer den vores energi og forestillinger til live. Den presser os til at gribe og blive konfronteret med den verden, som moderniseringsprocessen selv frembringer, og den presser os til at stræbe efter at gøre den til vor egen verden. Jeg tror, at vi - såvel som dem, der kommer efter os - vil fortsætte med at kæmpe for at blive hjemme i denne verden, selv om det hjem, vi har bygget - de moderne gader og den moderne ånd ryger i luften."

Hans Magnus Enzensbergers Ach Europa er gennemsyret af samme erfaring af den nuværende tingenes tilstand. 


\section{VII}

Vi har at gøre med et civilisatorisk træk, som konturerer sig tydeligere og tydeligere efter anden verdenskrig , hvor kapitalen for første gang egentlig internationaliseres, socialiteten globaliseres og verden bliver så lille, at enhver mystik vedrørende dens udstrækning på forhånd er outdatet. Her indtræffer, hvad vi kan kalde virkelighedens hverdagsagtiggørelse. Måske allervigtigst i dette internationale kulturelle hamskifte (som ikke står i modsætning til vækst i kulturel egenart og sektoral særegenhed) er det, at det ser ud til, at den moderne subjektivitet, der blev født i renaissancen, kan finde sig til rette med, føle sig hjemme i en verden - uden den sygdom i sjælen, som ellers hidtil har været dens kendetegn.

I filosofien - tværgående i forhold til stadig forekommende og relevante "ismeafgrænsninger" - kommer det civilisatoriske træk til udtryk i en ofte uudtalt, men ikke af den grund mindre effektiv konsensus om, at l) oprindelsesproblematikker forsvinder. Ursprungsproblematikker forlades til fordel for en altidallerede-væren, som er situeret. 2) Aprioriske invarianser antages ikke længere at gøre sig gældende på anden vis end analytisk, altså ikke syntetisk. 3) Der hersker en umelankolsk indstilling til endelighed og defundamentalisering. 4) Provisoriskhed - ses som grundvilkår for menneskelighed. Og 5) Nihilismens drama er ophørt med at have troværdighed.

Ingen anden filosofi har i den grad været med til at berede vejen for et sådant skifte i den filosofiske basis-konsensus som Wittgensteins.

Et vigtigt træk ved den pragmatiske vending i den filosofiske basis-konsensus er den gevaldige internationalisering af den filosofiske diskurs. Man skal uden tvivl tilbage til den kristne-latinsprogede enhedskultur i middelalderen for at finde noget - og da et bornert - modbillede.

I april i år blev der i anledning af 100-året for Wittgensteins fødsel holdt et stort og internationalt bredt orienteret symposium i selveste frankfurterskolens højborg Goetheuniversitetet i Frankfurt. Og ikke nok med denne anerkendelse af Wittgenstein. Fire af de vigtigste forelæsninger - Karl-Otto Apels, Richard Rortys, Jürgen Habermas/ og Charles Taylors - handlede eksplicit om Wittgenstein og Heidegger. Enhver, der kender bare lidt til den forkrøblende lejrtænkningstradition, der har gjort sig gældende for de store filosofiske traditioner i vores århundrede, vil ikke kunne undgå at bemærke, at noget nyt er under opsejling.

Wenn Einer uns fragte "Aber ist das WAHR?", könnten wir ihm sagen "Ja"; und wenn er Gründe verlangte, so könnten wir sagen "Ich kann dir keine Gründe geben, aber wenn du mehr lernst wirst du auch dieser Meinung sein". Käme es nun nicht dahin, so hiesse das, dass er, z.B., Geschichte nicht lernen kann (Wittgenstein). 